\title{
Funkcjonowanie Rejestru Sprawców Przestępstw na Tle Seksualnym na podstawie badań ankietowych i danych statystycznych
}

\author{
Applicability of the Sex Offenders Registry based on the survey \\ and statistical data
}

\section{Wprowadzenie}

Z dniem 1 października $2017 \mathrm{r}$. w polskim porządku prawnym zaczęła obowiązywać ustawa $\mathrm{z}$ dnia 13 maja $2016 \mathrm{r}$. o przeciwdziałaniu zagrożeniom przestępczością na tle seksualnym (tekst jedn. Dz.U., 2020, poz. 152; dalej: PrzesSeks). Zasadniczym celem ustawy jest zapewnienie bezpieczeństwa i porządku publicznego poprzez ochronę społeczeństwa przed sprawcami przestępstw na tle seksualnym. Dla urzeczywistnienia założeń powyższego aktu prawnego wprowadzono, na wzór innych państw ${ }^{1}$, sformalizowane reguły postępowania wobec sprawców przestępstw na tle seksualnym. W szczególności ustanowione zostały szczególne środki ochrony przeciwdziałające zagrożeniom przestępczości na tle seksualnym w postaci: Rejestru Sprawców Przestępstw na Tle Seksualnym (dalej: RSPTS), obowiązków pracodawców i innych organizatorów w zakresie działalności związanej z wychowaniem, edukacją, wypoczynkiem, leczeniem małoletnich lub z opieką nad nimi oraz określenia miejsc szczególnego zagrożenia przestępczością na tle seksualnym (zob. Wolska-Bagińska, Bagiński, 2018, s. 45-55; Kwieciński, 2017, s. 383-394; Warylewski, 2016, s. 33-47). Ustawa o przeciwdziałaniu zagrożeniom przestępczością na tle seksualnym kładzie nacisk na rozbudowę aktywnych środków ochrony służących jej zapobieganiu, w szczególności na środki prewencyjne (Rękas, 2017, s. 312-322). Pomimo słusznych celów, jakie legły

1 Podstawowym wzorcem prawnym przy tworzeniu ustawy były rozwiązania prawne przyjęte w innych krajach, w tym zwłaszcza regulacje przewidziane w Stanach Zjednoczonych Ameryki Północnej. 
u podstaw uchwalenia ustawy, rozwiązania w niej przyjęte od samego początku obowiązywania wzbudzały wiele kontrowersji (zob. Sakowicz, 2015, s. 149-161). Wątpliwości wokół tego aktu związane były nie tylko z kwestią zasadności wprowadzenia zupełnie nowych szczególnych środków ochrony, które mają chronić obywateli przed przestępczością skierowaną przeciwko wolności seksualnej, lecz także wiązały się z poważnymi wątpliwościami natury konstytucyjnej (Jarząbek-Bielecka i in., s. 176-181). Z danych statystycznych Komendantów Wojewódzkich Policji i Komendanta Głównego Policji oraz z badań przeprowadzanych przez instytucje zajmujące się pomocą ofiarom przestępstw seksualnych wynika, że od 2014 r. odnotowuje się spadek przestępczości na tle seksualnym (Statystyki Komendy Głównej Policji za lata 2000-2010; Statystyki Komendy Głównej Policji za lata 1990-2013). W toku procesu legislacyjnego szereg zastrzeżeń co do postanowień ustawy zgłosiły m.in. takie organy jak: Sąd Najwyższy, Rzecznik Praw Dziecka czy Generalny Inspektor Ochrony Danych Osobowych (pismo SN, 2016, BSA II-021-12/16, pismo Rzecznika Praw Dziecka, 2016). Poważne zarzuty wobec ustawy przedstawiane były także przez pozarządowe organizacje, $w$ tym przez Helsińską Fundację Praw Człowieka (zob. opinia Helsińskiej Fundacji Praw Człowieka, 2016). Opinie i stanowiska organów państwowych i pozarządowych w wielu aspektach są zbieżne i odnoszą się zwłaszcza do środka ochrony, jakim jest RSPTS .

\section{Rejestr Sprawców Przestępstw na Tle Seksualnym - dane statystyczne}

Pomimo wątpliwości, jakie budzi nowy środek ochrony w postaci RSPTS, nie odnotowano zestawień $i$ analiz dotyczących jego funkcjonowania w praktyce. Brak jest w szczególności publicznych danych co do liczby: osób w nim figurujących, zapytań dotyczących udostępnienia danych, podmiotów usuniętych z RSPTS czy zmian w nim dokonywanych. Dane prezentujące powyższe elementy niewątpliwie wywarłyby znaczący wpływ na ocenę realizacji zadań przedmiotowej instytucji, w tym praktycznej jej przydatności. W obliczu powyższych uwag stwierdzić należy, że czynnikami gwarantującymi dokonanie właściwej oceny omawianego środka ochrony oraz przedstawienia rzetelnych danych w zakresie jego wykorzystania w praktyce mogą okazać się rzeczywiste dane na temat jego działania.

$\mathrm{Z}$ uwagi na wagę danych dotyczących omawianej instytucji zwrócono się do Biura Informacyjnego Krajowego Rejestru Karnego o przekazanie informacji na temat funkcjonowania RSPTS, który to organ w myśl art. 4 ust. 2 PrzesSeks 
realizuje zadania związane z prowadzeniem RSPTS, w tym w zakresie przetwarzania w nim danych osobowych ${ }^{2}$. Zapytanie to, ze względu na obszar danych gromadzonych w RSPTS, dotyczyło tylko najistotniejszych kwestii odnoszących się do procesu przetwarzania informacji osobowych. Przedmiot badań objął okres od dnia wejścia w życie ustawy do czerwca 2020 r. Czasookres badania podyktowany był chęcią prezentacji możliwie najbardziej aktualnych danych, które zważywszy na stosunkowo nieodległy czas obowiązywania przedmiotowej ustawy, odzwierciedlają kształtującą się praktykę w zakresie stosowania jej przepisów.

Podstawową i niezbędną informacją do przeprowadzenia analizy była liczba osób wpisanych do RSPTS. Z uzyskanych informacji wynika, że od dnia wejścia w życie ustawy do czerwca 2020 r. ujawniono w nim łącznie 5019 osób. Z uwagi, że utworzony na mocy ustawy o przeciwdziałaniu zagrożeniom przestępczością na tle seksualnym RSPTS obejmuje dwie bazy danych, tj. Rejestr z dostępem ograniczonym oraz Rejestr publiczny, postanowiono uzyskać także dane co do liczby osób zamieszczonych w poszczególnych bazach. Z przekazanych informacji wynika, że w Rejestrze z dostępem ograniczonym w 2020 r. umieszczono 600 osób, a w Rejestrze publicznym - 227. W 2019 r. liczba umieszczonych w Rejestrze z dostępem ograniczonym wynosiła 1117, w Rejestrze publicznym - 359 osób. Natomiast w 2018 r. ujęto w Rejestrze dostępem ograniczonym 2513 osób, a w Rejestrze publicznym 203. Z powyższych danych wynika, że w latach 2019-2020 liczba osób umieszczonych w Rejestrze z dostępem ograniczonym była 3-krotnie większa od liczby osób wpisanych do Rejestru publicznego. Natomiast w $2018 \mathrm{r}$. współczynnik osób ujętych odpowiednio w Rejestrze z dostępem ograniczonym był 12-krotnie wyższy od współczynnika osób ujętych w Rejestrze publicznym. Znacząca liczba osób wpisanych do Rejestru w 2018 r. wynika z faktu, że wraz z jego utworzeniem wpisowi podlegały wszystkie osoby, które spełniały wymogi określone w art. 6 PrzesSeks.

Mając na względzie, że zaprezentowane powyżej informacje przedstawiają jedynie ogólną skalę podmiotów wpisanych do Rejestru, nie obrazując z kolei rozróżnienia kategorii osób figurujących w Rejestrze, zwrócono się również o wskazanie liczby osób ujętych w Rejestrze w ramach poszczególnych grup określonych w art. 6 PrzesSeks. Przedmiotowe badania umożliwiły na procentowe porównanie poszczególnych podmiotów funkcjonujących w Rejestrze w ramach danej grupy ze wszystkimi osobami wpisanymi do Rejestru.

2 Przy piśmie z dnia 15 października 2020 r., w sprawie o sygn. B-KRK-I.762.1.2020 oraz przy piśmie z dnia 18 maja 2018 r., w sprawie o sygn. B-KRK-I-762-1/18 otrzymano od Biura Informacyjnego Krajowego Rejestru Karnego dane statystyczne dotyczące RSPTS. 
Na podstawie otrzymanych danych ustalono, że w Rejestrze z dostępem ograniczonym wpisano w 2018 r. 2119 osób prawomocnie skazanych za popełnienie przestępstw, o których mowa w art. 2 PrzesSeks. W 2019 r. liczba ta wynosiła 1124 osoby, a w 2020 r. - 601. W Rejestrze z dostępem ograniczonym umieszczono od 2018 r. do czerwca 2020 r. 77 osób, wobec których prawomocnie orzeczono środki zabezpieczające. Natomiast $\mathrm{w}$ analizowanym okresie dokonano wpisu do Rejestrów 28 osób, przeciwko którym prawomocnie warunkowo umorzono postępowanie karne w sprawach o przestępstwa, o których mowa w art. 2 PrzesSeks. Do Rejestru z dostępem ograniczonym w badanym okresie wpisano 168 osób nieletnich, o których mowa w art. 6 ust. 1 pkt 4 PrzesSeks (Wolska-Bagińska, 2018, s. 63-70).

Z kolei w 2018 r. 162 osoby zostały umieszczone w Rejestrze publicznym w związku z popełnieniem czynu z art. $197 \$ 3$ pkt 2 lub $₫ 4$ k.k. W kolejnych latach liczba ta wynosiła odpowiednio 268 i 163 osoby. Powyższe dane wskazują, że w Rejestrze z dostępem ograniczonym osoby, które prawomocnie zostały skazane, stanowią ponad $90 \%$ wszystkich osób wpisanych do tego Rejestru, 1,8\% zaś stanowią ci, wobec których prawomocnie orzeczono środki zabezpieczające. W przypadku Rejestru publicznego prawie $80 \%$ to osoby, wobec których w kwalifikacji prawnej przyjętej w orzeczeniu powołano art. $197 \S 3$ pkt 2 lub art. $197 \S 4$ k.k.

Kolejna informacja podlegająca ocenie dotyczyła podmiotów uzyskujących dostęp do informacji o osobie ujętej w Rejestrze. Zauważyć należy, że dostęp do Rejestru publicznego ma każda osoba. Jest on bowiem ogólnodostępny w internecie na stronie Biuletynu Informacji Publicznej Ministerstwa Sprawiedliwości. Z kolei prawo do uzyskania informacji o osobie ujętej w Rejestrze z dostępem ograniczonym przysługuje sądom, prokuratorom czy Policji. Uprawnienie do uzyskania danych z Rejestru z dostępem ograniczonym nadane zostało nie tylko organom państwowym, lecz również innym instytucjom, które wiążą swoją działalność z kontaktami z dziećmi. Te ostatnie, czyli takie podmioty jak: szkoły, przedszkola oraz fundacje, mogą pozyskiwać z Rejestru z dostępem ograniczonym dane o osobach ujętych w Rejestrze (Michałkiewicz, 2016, s. 61). Prawo do uzyskania informacji o osobie ujętej w Rejestrze z dostępem ograniczonym przysługuje więc szerokiemu kręgowi podmiotów (Mierzwińska-Lorencka, 2016, s. 160).

Co istotne, zasady i tryb uzyskiwania danych z Rejestru zostały określone w rozporządzeniu Ministra Sprawiedliwości z dnia 31 lipca 2017 r. w sprawie trybu, sposobu i zakresu uzyskiwania i udostępniania informacji z Rejestru z dostępem ograniczonym oraz sposobu zakładania konta użytkownika (tekst jedn. Dz.U., 
2017, poz. 1561). Zgodnie z $\$ 2$ ust. 3 rozporządzenia podmioty, o których mowa w art. 12 pkt 1-3 PrzesSeks, a więc organy ścigania i wymiaru sprawiedliwości, uzyskują informacje z Rejestru za pośrednictwem systemu teleinformatycznego, o którym mowa w ust. 1, lub za pośrednictwem elektronicznej aplikacji dostępowej tych podmiotów. Uzyskanie informacji przy użyciu systemu dokonuje się kolejno przez: podanie identyfikatora użytkownika oraz hasła; wypełnienie pytania do systemu i opatrzenie pytania podpisem elektronicznym. Uprawnione podmioty wskazują w pytaniu zadanie lub postępowanie, w związku z którym zachodzi konieczność uzyskania informacji z Rejestru, oraz dane podlegające gromadzeniu w tym Rejestrze lub ich części. Jeżeli odpowiadają one tym zgromadzonym w Rejestrze, wnioskujący uzyskuje informację obejmującą wszystkie dane tam zgromadzone, należące do osoby albo osób, których dane odpowiadają danym tym wskazanym w pytaniu wraz z informacjami w nim zawartymi. Z kolei, jeżeli dane wskazane w pytaniu nie odpowiadają tym zgromadzonym w Rejestrze, osoby uprawnione uzyskują informację o treści „W Rejestrze nie ma informacji o osobach, dla których są spełnione warunki zawarte w pytaniu do systemu" wraz z danymi wskazanymi w pytaniu. W przypadkach, o których mowa w art. 19 ust. 3 PrzesSeks ustawy, podmiot uprawniony uzyskuje komunikat o treści „Trwa postępowanie w celu ustalenia prawidłowych danych. Uzyskanie informacji będzie możliwe po jego zakończeniu" wraz z danymi wskazanymi w pytaniu.

Z uwagi, że przepis art. 12 PrzesSeks umożliwia uzyskanie informacji zgromadzonych w Rejestrze $\mathrm{z}$ dostępem ograniczonym przez rożne podmioty $\mathrm{i}$ instytucje, analizie poddano jedynie wybrane kategorie osób, a następnie porównano je procentowo. Na przestrzeni badanego okresu 163 sędziów zwróciło się o udostępnienie danych umieszczonych w Rejestrze z dostępem ograniczonym. W przedmiotowym okresie wystosowano jedno zapytanie ze strony Prokuratury, a ze strony Policji osiemnaście. Odnotowano z kolei 601356 wniosków kierowanych przez pracodawców i innych organizatorów, tj. przez podmioty wskazane w art. 12 pkt 6-7 PrzesSeks. Natomiast 23588 zapytań wystosowały osoby w zakresie uzyskania informacji, czy ich dane są zgromadzone w tym Rejestrze, tj. osoby wskazane w art. 12 pkt 8 PrzesSeks. Odnotowano 626513 przypadków, w których podmioty wskazane w art. 12 pkt 1-7 PrzesSeks, oraz osoba, o której mowa w art. 12 pkt 8 PrzesSeks, uzyskały informacje o treści: „W Rejestrze nie ma informacji o osobach, dla których są spełnione warunki zawarte w pytaniu" wraz z danymi wskazanymi w pytaniu. W 2018 r. 568 osób w przedmiotowym okresie otrzymało komunikat o treści: „Trwa postępowanie w celu ustalenia prawidłowych danych. Uzyskanie informacji będzie możliwe po jego zakończeniu" wraz z danymi wskazanymi w pytaniu. W 2019 r. liczba ta wynosiła 715 osób, 
a w 2020 r. - 419. Jedynie w 5 przypadkach powyższe podmioty otrzymały informację o treści: „FIGURUJE” wraz z informacjami wskazanymi w zapytaniu.

W związku z tym, że ustawa o przeciwdziałaniu zagrożeniom przestępczości na tle seksualnym wprowadza ograniczenie czasowe przetwarzania danych osobowych w Rejestrze, uznano, że informacje na temat operacji usunięcia danych mogą stanowić istotną okoliczność dotyczącą funkcjonowania Rejestru. Zwrócić należy uwagę, że wobec każdej z czterech przewidzianych w art. 6 ust. 1 pkt 1-4 PrzesSeks kategorii osób, których dane są ujęte w Rejestrze, ustawa w art. 18 przewiduje odmienne terminy i podstawy usuwania ich danych osobowych z Rejestru. Stąd też kolejno przeanalizowano również badaną daną liczbę osób usuniętych z Rejestru oraz powody przeprowadzenia tej operacji.

Z przekazanych przy piśmie z dnia 18 maja 2018 r. przez Biuro Informacyjne Krajowego Rejestru Karnego danych wynika, że usunięto dane 52 osób figurujących w Rejestrze, z czego 35 wpisów dotyczyło podmiotów wpisanych do Rejestru z dostępem ograniczonym, a 17 zamieszczonych w Rejestrze publicznym. Powody usunięcia informacji z Rejestru związane były: ze zgonem osoby zamieszczonej w Rejestrze, zatarciem z mocy prawa skazań czy stwierdzeniem okoliczności wskazujących na wprowadzenie do Rejestru danych sprzecznych z treścią orzeczenia lub nieodpowiednim zapisom w odpowiednich dokumentach albo niezgodnych ze stanem faktycznym. Biuro Informacyjne Krajowego Rejestru Karnego stwierdziło 2 przypadki, w których wystąpiło prawdopodobieństwo wprowadzenia do Rejestru danych osobowych sprzecznych z treścią orzeczenia lub nieodpowiadających zapisom w odpowiednich dokumentach albo niezgodnych ze stanem faktycznym.

Przy piśmie z dnia 15 października 2020 r. Biuro Informacji Krajowego Rejestru Karnego wskazało, że z uwagi na brak prowadzenia ewidencji usuniętych dokumentów, jak również przyczyn ich usunięcia nie jest możliwe udzielenie odpowiedzi odnośnie do osób, których dane zostały usunięte z Rejestru. Biuro Informacji Krajowego Rejestru Karnego poinformowało również o braku możliwości przekazania informacji o stwierdzonych okolicznościach wskazujących na prawdopodobieństwo wprowadzenia do Rejestru danych osobowych sprzecznych z treścią orzeczenia lub nieodpowiadających zapisom w odpowiednich dokumentach albo niezgodnych ze stanem faktycznym.

Zaakcentować w tym miejscu należy, że oparty na danych osobowych Rejestr Sprawców Przestępstw na Tle Seksualnym może spełniać swoje funkcje tylko wówczas, gdy zawiera merytorycznie poprawne dane osobowe osób w nim zamieszczonych. Zapewnienie tej poprawności wymaga weryfikacji informacji osobowych zgromadzonych w Rejestrze. Powyższe ma służyć zapobieżeniu 
ewentualnym nieprawidłowościom w procesie przetwarzania danych w Rejestrze. Dlatego też niezbędne było ustalenie, czy w analizowanym okresie podejmowane były czynności służące ocenie prawidłowości wprowadzonych do Rejestru danych osobowych. Z otrzymanych informacji wynika, że w oparciu o przepis art. 19 PrzesSeks dokonano zmian danych osobowych zgromadzonych w Rejestrze. Dotyczyły one zmiany informacji osobowych w Krajowym Rejestrze Karnym zaistniałych w wyniku sprostowania danych podawanych w kartach rejestracyjnych przez sąd oraz poprzez aktualizację danych przesyłanych przez Centralny Zarząd Służby Więziennej.

\section{Rejestr Sprawców Przestępstw na Tle Seksualnym - badania ankietowe}

Przeprowadzona analiza danych statystycznych wykazała, że pomimo znacznej liczby osób wpisanych do RSPTS organy uprawnione do uzyskania informacji w niewielkim stopniu zwracały się o udostępnienie danych. Co istotne, w analizowanym okresie brak było zapytań kierowanych ze strony organów ścigania i wymiaru sprawiedliwości. W artykule podjęto więc próbę wyjaśnienia powodów tej sytuacji braku zapytań. Ustalenie przyczyn takiego stanu rzeczy wymagało uzyskania od osób uprawnionych do otrzymania danych na postawie art. 12 pkt 1-3 PrzesSeks opinii na temat działania RSPTS. Nie ulega wątpliwości, że od stanu wiedzy oraz nastawienia organów uprawnionych do dostępu do danych zgromadzonych w Rejestrze zależy wykorzystanie tej instytucji w praktyce. Stąd też tak ważne jest poznanie poglądów i ocen tych podmiotów odnośnie do jego funkcjonowania.

Mając na względzie, że szczególną rolę w zwalczaniu przestępczości na tle seksualnym odgrywają organy ścigania, przeprowadzono wśród prokuratorów aktywnych zawodowo badanie ankietowe. W celu uzyskania opinii praktyków na temat RSPTS poproszono o wypełnienie ankiety prokuratorów czynnych zawodowo. Starano się sprawdzić, czy opinie i stosunek do możliwości uzyskiwania danych z RSPTS są podobne wśród prokuratorów Prokuratur Rejonowych w poszczególnych okręgach Prokuratury Regionalnej w Gdańsku, czy też różnią się od siebie. W tym celu, aby tę porównywalność osiągnąć, do prokuratorów skierowano anonimową ankietę indywidualną za pośrednictwem czterech Prokuratur Okręgowych, tj. Prokuratury Okręgowej w Bydgoszczy, Gdańsku, Toruniu i Słupsku. Przeprowadzona analiza pozwoliła na uchwycenie pewnych wzorców postępowań prokuratorów oraz ich stosunku do omawianej instytucji. 
Udzielone odpowiedzi umożliwiły również zestawienie (porównanie) danych statystycznych uzyskanych od Biura Informacyjnego Krajowego Rejestru Karnego z danymi otrzymanymi od prokuratorów w zakresie wykorzystywania tej instytucji w praktyce prokuratorskiej.

W ramach przeprowadzonych badań uzyskano łącznie 207 ankiety, z czego 84 zostały wypełnione przez prokuratorów z obszaru Prokuratury Okręgowej w Gdańsku, 60 z Prokuratury Okręgowej w Bydgoszczy, 39 z Prokuratury Okręgowej w Toruniu oraz 24 z Prokuratury Okręgowej w Słupsku. Ankieta składała się z 10 pytań zamkniętych dotyczących problematyki RSPTS.

Pierwsze pytanie miało na celu ustalenie, czy prokuratorzy zapoznali się z treścią ustawy z dnia 13 maja 2016 r. o przeciwdziałaniu zagrożeniom przestępczością na tle seksualnym i aktami wykonawczymi do tej ustawy. Z uzyskanych odpowiedzi wynika, że znaczna część prokuratorów nie zna treści ustawy, albowiem z 207 ankietowanych jedynie 99 zadeklarowało znajomość jej przepisów, 4 osoby odnotowały na ankiecie, iż zapoznały się tylko z treścią ustawy. Wśród prokuratorów z obszaru Prokuratury Okręgowej w Gdańsku na 84 badanych tylko 37 prokuratorów wskazało, że przeczytało komentowaną ustawę, tj. 44\% ankietowanych. Nieco więcej, albowiem 45\% prokuratorów z okręgu Prokuratury Okręgowej w Słupsku i 58\% prokuratorów z okręgu Prokuratury Okręgowej w Bydgoszczy zadeklarowało znajomość ustawy. Natomiast aż 74\% badanych z okręgu Prokuratury Okręgowej w Toruniu wskazało na fakt zapoznania się z treścią ustawy i aktów wykonawczych.

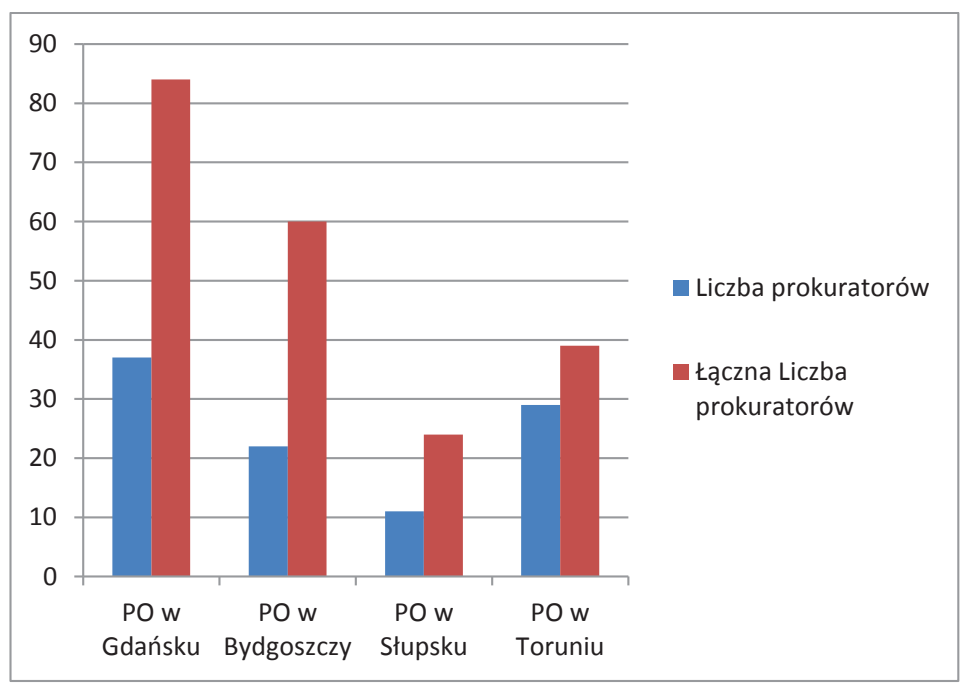

Źródło: opracowanie własne. 
Konsekwencją pierwszego pytania było ustalenie, czy prokuratorzy posiadają wiedzę odnośnie do procedury uzyskiwania informacji z Rejestru z dostępem ograniczonym. Deklaracje respondentów wskazują, że tylko 71 z nich posiada wiedzę na temat procedury uzyskiwania danych z Rejestru. Najniższy odsetek badanych deklarujących znajomość zasad udostępniania danych występuje wśród prokuratorów z obszaru Prokuratury Okręgowej w Gdańsku i wynosi 27\% badanych, najwyższy zaś - wśród prokuratorów z obszaru Prokuratury Okręgowej w Toruniu: 64\% ankietowanych. Natomiast wynik w przypadku prokuratorów z obszaru Prokuratury Okręgowej w Bydgoszczy kształtuje się na poziomie 39\%, w przypadku zaś prokuratorów z obszaru Prokuratury Okręgowej w Słupsku $-45 \%$.

Powyższe dane nie korespondują jednak z odpowiedziami zadeklarowanymi w pierwszym pytaniu ankiety. Wydawać by się mogło, że w sytuacji w której 95 prokuratorów wskazuje pozytywną odpowiedź co do znajomości aktów wykonawczych omawianej ustawy, to automatycznie ci sami respondenci powinni zakreślić pozytywną odpowiedź odnośnie do procedury pozyskiwania danych z Rejestru, która de facto została określona w przedmiotowych aktach wykonawczych. Wyniki te przekładają się na liczbę zapytań o udostępnienie informacji z Rejestru z dostępem ograniczonym za pośrednictwem systemu teleinformatycznego lub elektronicznej aplikacji dostępowej.

Zauważyć należy, iż pomimo że 101 ankietowanych uznało Rejestr z dostępem ograniczonym za cenne źródło informacji dla organów ścigania na temat osoby w nim ujętej, to jednak żaden z prokuratorów w analizowanym okresie nie zwrócił się o udostępnienie informacji za pośrednictwem systemu teleinformatycznego lub elektronicznej aplikacji dostępowej. Znamienny jest z kolei fakt, że 49 ankietowanych wskazało, że dokonywało sprawdzeń na stronie internetowej Biuletynu Informacji Publicznej Ministerstwa Sprawiedliwości odnośnie do figurowania danej osoby w Rejestrze publicznym.

Co istotne, na podstawie przeprowadzonych badań ustalono, że w okresie od 1 października 2017 r. do dnia wypełnienia przedmiotowej ankiety 110 prokuratorów zadeklarowało, iż prowadziło (nadzorowało) postępowanie o czyny zabronione obejmujące przestępstwa przeciwko wolności seksualnej wymienione w rozdziale XXV ustawy z dnia 6 czerwca 1997 r. - Kodeks karny (tekst jedn. Dz.U., 2020, poz. 1444).

W toku dalszych badań starano się poznać opinię respondentów w kwestii dostępności szeregu danych osobowych podmiotów wpisanych do Rejestru publicznego. W ramach przeprowadzonych badań było to zagadnienie o tyle istotne, że opinia badanych w tym przedmiocie mogła mieć wpływ na ich po- 
glądy dotyczące konkretnych rozwiązań prawnych, ich represyjności i skuteczności bądź jej braku. Kolejnym pytaniem, na które odpowiedzieli ankietowani prokuratorzy, było zagadnienie dostępu każdego obywatela za pośrednictwem jawnego Rejestru do danych osobowych sprawców przestępstw z art. $197 \$ 3$ pkt 2 lub 4 k.k. oraz tych, którzy dopuścili się przestępstwa na tle seksualnym, będąc uprzednio skazanymi na karę pozbawienia wolności bez warunkowego zawieszenia jej wykonania za przestępstwo na tle seksualnym popełnione na szkodę małoletniego za pośrednictwem jawnego Rejestru. W ocenie 102 ankietowanych dostęp do danych osobowych sprawców na tle seksualnym nie powinny mieć osoby trzecie, tj. każdy obywatel. Za dostępem każdego obywatela do informacji ujętych w Rejestrze publicznym opowiedziało się 70 badanych prokuratorów. Z kolei 35 ankietowanych nie wyraziło $\mathrm{w}$ tym przedmiocie stanowiska.

Prokuratorzy w większości negatywnie oceniali aktualnie funkcjonujący instrument prawny zwalczania liczby ponownych przestępstw seksualnych w postaci Rejestru. Na 207 badanych prokuratorów aż 99 wskazało, że Rejestr publiczny nie wpływa na zmniejszenie liczby ponownych przestępstw seksualnych. Odmiennego zdania było 59 badanych, 49 ankietowanych zaś nie opowiedziało się za żadną z tych odpowiedzi.

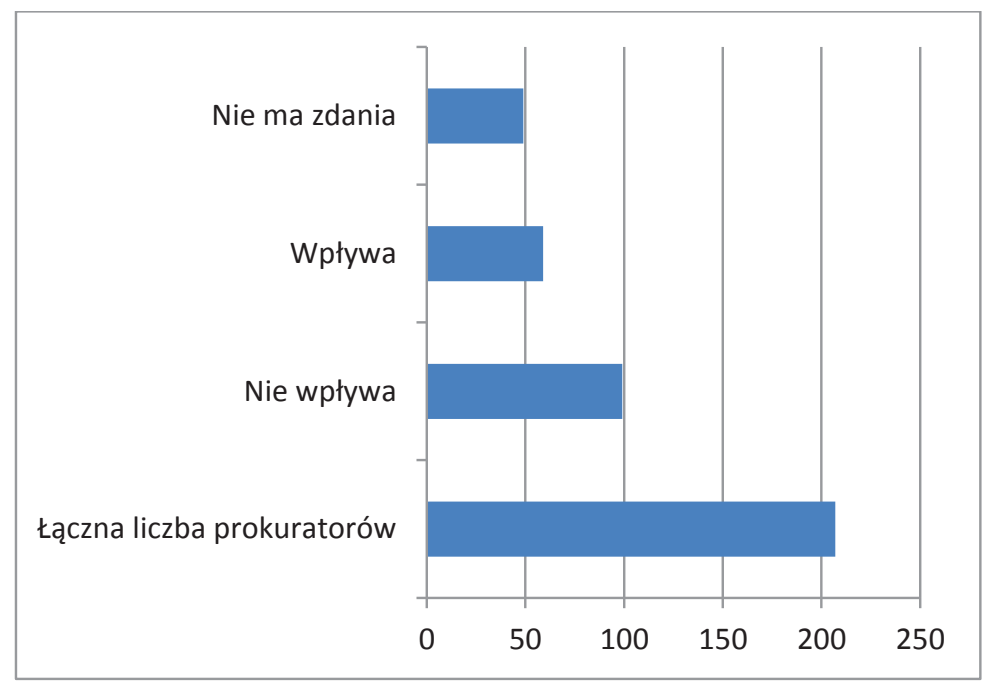

Źródło: opracowanie własne.

Stanowisko części prokuratorów w tym przedmiocie jest zbieżne z poglądem Polskiego Towarzystwa Seksuologicznego, które w uchwale z dnia 22 stycznia 2016 r. podniosło, że ogólnodostępny Rejestr sprawców przestępstw na tle sek- 
sualnym nie stanowi skutecznego środka ochrony mającego przyczynić się do zmniejszania zagrożenia przestępczością seksualną (Uchwała, 2016). Z kolei w opinii 108 badanych prokuratorów wprowadzenie do polskiego porządku prawnego środka ochrony społeczeństwa przed przestępczością seksualną w postaci Rejestru publicznego może wiązać się z istotnymi zagrożeniami dla sprawcy. $\mathrm{Na}$ tle doświadczeń amerykańskich można dostrzec, że sprawcy ujawnieni w rejestrze są narażeni m.in. na utratę stanowisk pracy i mieszkania oraz są nękani przez najbliższe otoczenie (Jacobs, 2016).

\section{Zakończenie}

Rozważania poczynione $w$ artykule pozwoliły na konstatację, że choć w intencji ustawodawcy zgromadzone w RSPTS dane stanowić miały cenne źródło wiedzy dla organów ścigania i wymiaru sprawiedliwości, to jednak praktyka wykazuje, że nie są one przez nie w ogóle wykorzystywane. Opierając się na wynikach ankiety, można wysnuć tezę, że prokuratorzy nie występują z zapytaniami ze względu na brak wiedzy co do możliwości i trybu uzyskiwania danych z Rejestru. Powyższy stan może wynikać po pierwsze z nieznajomości aktów normatywnych dotyczących omawianej instytucji lub też tylko z ich pobieżnej analizy. Nie wydaje się, aby powodem braku wystąpień była kwestia procedury pozyskiwania danych. Aktualnie w jednostkach organizacyjnych prokuratury istnieją bowiem podobnie funkcjonujące systemy uzyskiwania informacji, z których organy ścigania pozyskują i wykorzystują dane w nich zgromadzone w codziennej praktyce. Wpływ na liczbę zapytań może mieć natomiast okoliczność, że informacje osobowe odnośnie do sprawcy przestępstw na tle seksualnym można uzyskać w oparciu o dane figurujące $w$ innych systemach pozostających $w$ dyspozycji organów ścigania. Brak pozyskiwania danych z rejestru wynika również z fakultatywnego charakteru tej instytucji, który łączyć należy z praktyką ograniczenia (minimalizacji) podejmowanych przez ograny procesowe w tym zakresie czynności w związku z ich wpływem na motorykę postępowania. Także negatywne bądź ambiwalentne nastawienie prokuratorów do omawianej instytucji oddziałuje na zakres jej wykorzystania. Stanowisko części z ankietowanych prokuratorów wykazuje, że RSPTS nie wpływa na zmniejszenie liczby ponownych przestępstw seksualnych. Dokonując z kolei prognozy funkcjonowania omawianej instytucji, uznać należy, że przepisy dotyczące udostępniania danych z Rejestru z dostępem ograniczonym nie będą w ogóle wykorzystywane przez organy ścigania dla potrzeb prowadzonych postępowań karnych. 


\section{Bibliografia}

\section{Akty prawne}

Ustawa z 6.06.1997 - Kodeks karny, tekst jedn. Dz.U., 2020, poz. 1444.

Ustawa z 13.05.2016 o przeciwdziałaniu zagrożeniom przestępczością na tle seksualnym³, tekst jedn. Dz.U., 2020, poz. 152.

Rozporządzenie Ministra Sprawiedliwości z dnia 31 lipca 2017 roku w sprawie trybu, sposobu i zakresu uzyskiwania i udostępniania informacji z Rejestru z dostępem ograniczonym oraz sposobu zakładania konta użytkownika, tekst jedn. Dz.U., 2017, poz. 1561.

Uchwała Zarządu Głównego Polskiego Towarzystwa Seksuologicznego z dnia 22.01.2016 r. Pobrano z http://pts-seksuologia.pl/sites/strona/50/uchwala-zarzadu-glownego-polskiego-towarzystwa-seksuologicznego-z-dnia-22012016r (25.05.2020).

\section{Literatura}

Jacobs, D. (2016). Why Sex Offender Laws Do More Harm Than Good, Opinia Helsińskiej Fundacji Praw Człowieka do rzadowego projektu ustawy o przeciwdziałaniu zagrożeniom przestępczości na tle seksualnym (druk 189) z dnia 8 lutego 2016 r. Pobrano z http://www.hfhr.pl/publiczny-rejestr-sprawcow-przestepstw-na-tle-seksualnym-uwagi-hfpc/ (25.05.2020).

Jarząbek-Bielecka, G., Buks, J., Lorkiewicz-Muszyńska, D., Labęcka, M., Jarząbek, M., Bielecka-Gąszcz, A. ...Opala, T. (2014). Przestępstwa wobec nieletnich, przestępstwa seksualne. Polski Przeglad Nauk o Zdrowiu, 2(39), 176-181.

Kwieciński, A. (2017). Ustawa o przeciwdziałaniu zagrożeniom przestępczością na tle seksualnym. W: Wykonywanie kary pozbawienia wolności w systemie terapeutycznym (s. 383-394). Warszawa: C.H. Beck.

Michałkiewicz, E. (2016). Rejestr Sprawców Przestępstw na Tle Seksualnym w aspekcie praw człowieka i obywatela. Prawo Mediów Elektronicznych, 2, 61.

Mierzwińska-Lorencka, J. (2016). Rejestr sprawców przestępstw seksualnych. Uwagi na tle ustawy z dnia 13 maja 2016 r. o przeciwdziałaniu zagrożeniom przestępczością na tle seksualnym. Studia Prawnicze, 4, 160.

Opracowanie Ministerstwa Sprawiedliwości. (b.d.). Skazania prawomocne - dorośli. Pobrano z https://isws.ms.gov.pl/pl/baza-statystyczna/opracowania-wieloletnie (25.05.2020).

\footnotetext{
Tekst jedn. Dz.U., 2016, poz. 862.
} 
Rękas, A. (2017). Pokrzywdzeni w szczególnych potrzebach. W: Z problematyki wiktymologii, Księga dedykowana Profesor Ewie Bieńkowskiej (s. 3122-323), red. W. Klaus, L. Mazowiecka, A. Tarwacka. Warszawa: Wolters Kluwer.

Sakowicz, A. (2015). Opinia prawna na temat projektu ustawy o przeciwdziałaniu zagrożeniom przestępczości na tle seksualnym i o zmianie niektórych innych ustaw. Zeszyty Prawnicze Biuro Analiz Sejmowych Kancelarii Sejmu 2015, 2(46), 149-161. Statystyki Komendy Głównej Policji za lata 2000-2010; Statystyki Komendy Głównej Policji za lata 1990-2013 (b.d.). Pobrano z http://statystyka.policja.pl/st/wybrane-statystyki/przestepczosc-nieletni/50256,dok.html (25.05.2020).

Statystyki Ministerstwa Sprawiedliwości, (b.d.). Pobrano z https://bip.ms.gov.pl/pl/ dzialalnosc/statystyki/statystyki-2010/ (25.05.2020).

Warylewski, J. (red.) (2016). Przestępstwa przeciwko wolności seksualnej i obyczajności. W: Przestępstwa przeciwko dobrom indywidualnym (s. 646-649). Warszawa: C.H. Beck.

Wolska-Bagińska, A. (2018). Ochrona praw i wolności nieletniego, a Rejestr Sprawców na Tle Seksualnym. Palestra, 9, 63-70.

Wolska-Bagińska, A., Bagiński, Ł. (2018). Rejestr Sprawców Przestępstw na Tle Seksualnym. Przedsiębiorstwo i Prawo, 3, 45-55.

\section{Streszczenie}

Celem artykułu była ocena danych statystycznych uzyskanych od Biura Informacyjnego Krajowego Rejestru Karnego na temat funkcjonowania Rejestru Sprawców Przestępstw na Tle Seksualnym. W artykule przedstawiono wyniki badań ankietowych przeprowadzonych wśród prokuratorów Prokuratur Rejonowych znajdujących się na obszarze właściwości Prokuratury Okręgowej w Bydgoszczy, Gdańsku, Słupsku i Toruniu. Wyniki badania stanowią pierwszą próbę zobrazowania danych statystycznych dotyczących Rejestru Sprawców Przestępstw na Tle Seksualnym oraz poglądów przedstawicieli polskich organów ścigania w przedmiocie stosowania nowego środka ochrony społeczeństwa przed sprawcami przestępstw na tle seksualnym.

SŁOWA KLUCzowe: Rejestr Sprawców Przestępstw na Tle Seksualnym, dane statystyczne, prokuratura, prawo dostępu.

\section{Summary}

This article aims at analysing the statistical data provided by the Information Office of the National Criminal Register regarding the Sex Offenders Registry. It also presents the results of the survey of prosecutors. The results of the conducted study constitute the first presentation of statistical data regarding the Sex Offenders Registry and attitudes of the representatives of Polish law enforcement towards the new means of protection against sex offenders. The analysis showed that even though the number of people entered into 
the Sex Offenders Registry is considerably large, the law enforcement and judiciary do not exercise their right to access the Registry. The main reason for not accessing the limited-access Registry by authorised authorities is the lack of knowledge as to how to apply for such access to the Register. This may result from unfamiliarity with the legislative acts concerning the Registry or their rough analysis.

KEYwORDS: Sex Offenders Registry, statistical data, prosecutors, right to access.

\section{Nota o autorze}

Anna Wolska-Bagińska - dr nauk prawnych, prokurator Prokuratury Rejonowej delegowany do Prokuratury Okręgowej w Gdańsku, wykładowca na Wydziale Prawa i Administracji Uniwersytetu Gdańskiego; e-mail: wolskaanna@vp.pl; ORCID: 0000-0002-6928-1416. 